\title{
Uncoupling of bacterial production and flagellate grazing in aquatic sediments: a case study from an intertidal flat
}

\author{
Ilse Hamels*, Koenraad Muylaert, Griet Casteleyn, Wim Vyverman \\ Protistology and Aquatic Ecology Section, Department of Biology, University of Gent, K.L. Ledeganckstraat 35, \\ 9000 Gent, Belgium
}

\begin{abstract}
In contrast to planktonic ecosystems, the fate of bacterial production in aquatic sediments is still largely unclear. In this study, we identified the factors regulating the impact of flagellate grazing on benthic bacterial production for a sandy and a silty intertidal sediment. Flagellate grazing rates were estimated using fluorescently labelled sediment to prevent disturbance of in situ bacterial density and community composition and to account for grazing on attached bacteria. Since flagellate cell size was quite diverse, the grazing rates were determined for 4 size classes. Bacterial production was measured simultaneously with grazing estimates. Bacterial density and production increased with decreasing median grain size of the sediment. Bacterial production was strongly related to the chlorophyll a content of the sediment, indicating resource control of bacterial production. In contrast to bacteria, flagellate biomass decreased with decreasing median grain size of the sediment. Pairwise comparison of grazing rates between the 2 sites showed that grazing rates were significantly higher at the sandy site. This suggests that the effect of sediment composition on flagellate biomass may be mediated by an influence of sediment characteristics on flagellate ingestion rates. The negative relation of bacterial production and the positive relation of flagellate biomass and grazing rates with median grain size resulted in a significant positive relation between the impact of flagellate grazing on bacterial production and the median grain size of the sediment. These results amount to an uncoupling of flagellate grazing and bacterial production in fine sediments. Our results as well as results from previous studies suggest that grazing by flagellates is not an important fate of bacterial production in aquatic sediments, except for sandy sediments during periods of low bacterial production.
\end{abstract}

KEY WORDS: Bacterivory - Heterotrophic flagellates · Grazing rates · Bacterial production · Intertidal sediments

\section{INTRODUCTION}

High rates of bacterial production have been measured in aquatic sediments (e.g. van Duyl \& Kop 1990, Cammen 1991, Hansen \& Alongi 1991). The fate of this production, however, is far from clear. In freshwater and marine pelagic systems, protozoa, especially heterotrophic nanoflagellates, have been identified as the major grazers of bacteria (Sanders et al. 1992, Sherr \& Sherr 1994). In sediments, micro-,

*E-mail: ilse.hamels@rug.ac.be meio- and macrobenthic organisms are potential consumers of bacteria. Macrobenthic animals seem to be incapable of consuming significant amounts of bacterial production (Kemp 1987, 1990). Studies dealing with the importance of meiofauna as grazers of bacteria in aquatic sediments have yielded contradictory results: meiofauna have been found to remove a major (e.g. Montagna 1984, 1995, Epstein 1997b) to only a minor (e.g. Epstein \& Shiaris 1992b, Borchardt \& Bott 1995, Sundbäck et al. 1996) part of bacterial standing stock and production. The study of protozoa in aquatic sediments has long been hampered by 
methodological problems, but ultimately, high densities of protozoa in general and heterotrophic flagellates in particular were revealed in several types of aquatic sediments (e.g. Hondeveld et al. 1994, Starink et al. 1996b). Despite their quantitative importance, however, most grazing studies revealed only a small impact of flagellate grazing on bacterial dynamics (e.g. Epstein \& Shiaris 1992b, Starink et al. 1996a).

It is hard to draw general conclusions about the importance of flagellate grazing as a fate for benthic bacterial production. This is due to the restricted number of sites studied, the fact that seasonality has only been included in a few studies and the fact that flagellate grazing and bacterial production have rarely been measured simultaneously. Besides, serious methodological problems may have resulted in an underestimation of grazing rates and hence underestimation of the impact of flagellates on bacterial production. The monodispersed fluorescently labelled bacteria (FLB) method, adopted from pelagic studies, has been most frequently used to measure bacterivory by benthic flagellates and ciliates. FLB used in these experiments usually originated from cultures of mixed bacterioplankton (Hondeveld et al. 1992, 1995) or monospecific cultures (Kemp 1988, Novitsky 1990, Epstein \& Shiaris 1992b). Frequently the size of these FLB differed strongly from the size of in situ benthic bacteria (Hondeveld et al. 1992, 1995). Differences in the composition of the in situ bacterial community and the bacterial community used as a tracer may influence grazing rate estimates because of selection for specific size classes (Epstein \& Shiaris 1992a, Hahn \& Höfle 1999) and/or species (Pérez-Uz 1996). Perhaps more important is the consideration that bacteria in sediments are mostly associated with sediment and detrital particles (Weisse \& Rheinheimer 1978). Several flagellate species show marked preferences for attached and aggregated bacteria (Caron 1987, Sibbald \& Albright 1988), so FLB should therefore be prepared from natural assemblages of free and attached bacteria. Starink et al. (1994b) used fluorescently labelled sediment for grazing experiments. In this way, grazing of free as well as attached FLB is measured. Comparing this method with the monodispersed FLB technique in lake sediments, Starink et al. (1994b) found about $\sim 2$-fold higher grazing rates with the use of stained sediment.

In the present study, bacterial grazing by heterotrophic flagellates is compared with bacterial standing stock and production at 2 sites with contrasting sediment characteristics on an intertidal flat in the Schelde estuary. We studied seasonal variability and identified the factors regulating the impact of flagellate grazing on the benthic bacterial community.

\section{MATERIALS AND METHODS}

Study site and sampling. Sediments were obtained from the Molenplaat, an intertidal flat in the polyhaline reaches of the Schelde estuary (SW Netherlands). Two sites (Fig. 1) were chosen on the basis of their sediment characteristics (for full site description see Middelburg et al. 2000 and Herman et al. 2000). The silty site (Molenplaat station 2) is located in the central, most protected region of the flat, while the sandy site (Molenplaat station 4) is subject to higher hydrodynamical disturbance.

The experiments were conducted in August, October and November 1998 and March and May 1999. Sediment was collected by hand coring during ebb tide. In the field, the sediment was carefully extruded through the top of the corer and the top $3 \mathrm{~mm}$ horizon was sliced off. Samples for bacterial and flagellate densities were taken using $10 \mathrm{ml}$ cut-off disposable syringes (inner diameter $16 \mathrm{~mm}$ ) with sharpened edges. Sediment slices were pooled and immediately fixed with an equal volume of filtered-sterilized formaldehyde $(2.5 \%$ final concentration) (3 slices, bacteria) or ice-cold glutaraldehyde ( $2 \%$ final concentration) (5 slices, flagellates). For the grazing experiments and the bacterial production measurements, sediment from 25 or 8 plexiglass cores (inner diameter $36 \mathrm{~mm}$ ) respectively was pooled and stored at in situ temperature. Additional replicate cores of $36 \mathrm{~mm}$ were collected for the determination of the grain size distribution (laser diffraction technique using a Coulter ${ }^{\circledR}$ LS 100 with fluid module, Coulter Electronics, Inc.). For the determination of chl a content (according to a slightly modified protocol of Mantoura \& Llewellyn 1983), 2 replicate cores of $16 \mathrm{~mm}$ were taken and immediately frozen using $\mathrm{CO}_{2}$ ice.

Bacterial and heterotrophic flagellate counts. Bacterial dislodgment from sediment and detritus particles was performed by sonication (with a $3 \mathrm{~mm}$ microtip, at a power level of $100 \mathrm{~W}$ ) for $60 \mathrm{~s}$ (Tso \& Taghon 1997) after incubation of samples for 30 min with a filtersterilized $5 \mathrm{mM}$ tetrasodium pyrophosphate/2\% $\mathrm{NaCl}$ solution (Velji \& Albright 1993). After proper dilution, a subsample was stained with acridine orange $(10 \mu \mathrm{g}$ $\mathrm{ml}^{-1}$ final concentration) and collected on a black $0.2 \mu \mathrm{m}$ Nuclepore polycarbonate filter. The bacteria of 15 fields (min. 500 bacteria) were counted immediately at $1000 \times$ magnification by epifluorescence microscopy using blue light illumination.

Flagellates were extracted from the sediment using isopycnic centrifugation (Starink et al. 1994a) within $12 \mathrm{~h}$ of sampling. Extracted flagellates were stained with DAPI ( $5 \mu \mathrm{g} \mathrm{ml}^{-1}$ final concentration) and collected on 1 and $5 \mu \mathrm{m}$ (for larger flagellates) Nuclepore polycarbonate filters. Filters were mounted on slides and stored frozen in the dark until enumeration, which 
Fig. 1. Schelde estuary, with the location of the sampling sites on the Molenplaat tidal flat

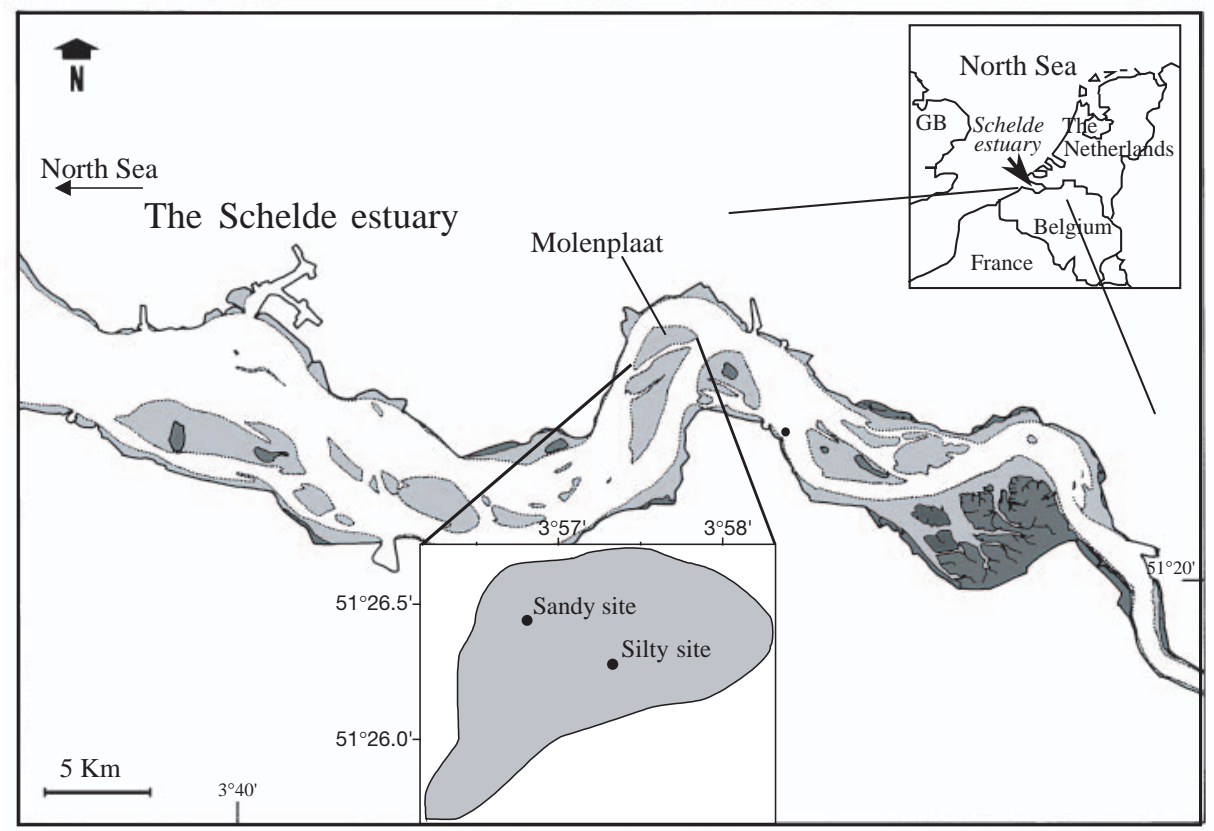

took place within 1 mo. Flagellates were counted using epifluorescence microscopy with UV excitation. Absence of chl a was checked by switching to blue light excitation. At least 100 randomly selected fields per filter were observed (magnification 1000x). Flagellates were classified by their longest linear dimension into 4 different size classes: $<5,5-9,10-19$ and $\geq 20 \mu \mathrm{m}$. Biovolumes were estimated assuming cells to have geometrical shapes and were converted to carbon biomass

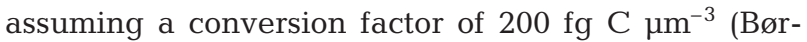
sheim \& Bratbak 1987, Sherr \& Sherr 1993a) for aldehyde fixed protozoa.

Bacterial production. Bacterial production measurements were started on board the RV 'Luctor' within $1 \mathrm{~h}$ after sampling. We used the ${ }^{3} \mathrm{H}$-leucine incorporation method, following an adaptation of the procedure used by van Duyl \& Kop (1994). In order to allow easy subsampling of the sediment from the silty site, sediment slurries were made by adding 3 to $5 \mathrm{ml}$ filtered ( $0.22 \mu \mathrm{m}$ Millipore) estuarine water to $15 \mathrm{ml}$ of sediment. For the sandy site, no water was added. $100 \mu \mathrm{l}$ subsamples of (diluted) sediment were pipetted with a cut-off tip into $2 \mathrm{ml}$ screw-capped tubes, which were placed in a water bath at the temperature of the Schelde water (see Fig. 2B). Subsequently $100 \mu \mathrm{l}$ of a leucine-solution was added and mixed carefully with the sediment. Isotope dilution was determined at both sites using 4 different leucine concentrations. A $100 \mu \mathrm{l}$ leucine solution contained $0.2,0.4,0.6$ or $0.8 \mathrm{nmol}$ leucine in August, October and May but 0.1, 0.2, 0.4 or $0.6 \mathrm{nmol}$ leucine in November and March. Independent of the total amount of leucine, the amount of labeled leucine (L- $\left[4,5-{ }^{3} \mathrm{H}\right]$ leucine, specific activity 133 to $157 \mathrm{Ci} \mathrm{mmol}^{-1}$, Amersham, Buckinghamshire, England), was 0.02 or $0.01 \mathrm{nmol}$ respectively, thus not exceeding $10 \%$. For each leucine concentration, 3 replicates and 1 blank were used. Bacteria in the blanks were killed before the addition of leucine by adding a cold $80 \%$ ethanol solution $(1.5 \mathrm{ml})$.

After 20 to $40 \mathrm{~min}$, the incubations were stopped by the addition of $1.5 \mathrm{ml}$ ice-cold $80 \%$ ethanol and stored in a refrigerator overnight. Samples were washed by resuspension/centrifugation $(8000 \times g, 3 \mathrm{~min})$ once with ice-cold ethanol $(80 \%)$ and 3 times with $5 \%$ icecold TCA (trichloroacetic acid). Macromolecules were subsequently extracted by adding $1.5 \mathrm{ml}$ of $\mathrm{NaOH}$ $(0.3 \mathrm{M})$, EDTA $(25 \mathrm{mM})$ and SDS $(0.1 \%)$ for at least $12 \mathrm{~h}$ at room temperature. The samples were then centrifuged $(1000 \times g, 5 \mathrm{~min})$ to remove the sediment particles. Of the supernatant, $1 \mathrm{ml}$ was transferred to glass scintillation vials containing $10 \mathrm{ml}$ of scintillation fluid (Lumasave plus, Lumac). The radioactivity was measured with a liquid scintillation counter (Beckman LS $6000)$ as disintegrations per minute (dpm). Quenching was accounted for by automatic external standardization. After subtraction of the blanks, the production was calculated using the following equation:

$$
\begin{aligned}
& \text { Production }\left(\mathrm{mgC} \mathrm{ml}^{-1} \mathrm{~h}^{-1}\right)= \\
& d p m \times \frac{60}{t} \times \frac{1}{\left(2.2 \times 10^{12}\right)} \times M \times \frac{1}{\% \text { Leu }} \times \mathrm{C} / \text { Prot } \times 10 \times \\
& \frac{\text { total Leu added }(\mathrm{nmol})+\text { isotope dilution }(\mathrm{nmol})}{S A \times\left[{ }^{3} \mathrm{H}\right] \text { Leu added }(\mathrm{nmol})}
\end{aligned}
$$


where $t=$ incubation time (min); $1 \mathrm{Ci}=2.2 \times 10^{12} \mathrm{dpm}$; $M=$ molecular weight of leucine; $\% L e u=$ fraction of leucine in protein $=0.073 ; \mathrm{C} /$ Prot $=$ Carbon $/$ Protein ratio $=0.86$ (Simon \& Azam 1989); $S A=$ specific activity of the leucine added in $\mathrm{Ci} \mathrm{mmol}^{-1}$

Bacterial cell production was estimated using a mean bacterial volume of $0.14 \mu^{3}$ per cell (mean value based on Cammen \& Walker 1986, Hondeveld et al. 1992, van Duyl \& Kop 1990, Kuwae \& Hosokawa

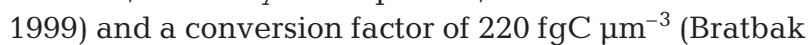
\& Dundas 1984).

Preparation of stained sediment. Two days before the actual grazing experiment, sediment was collected at the 2 sites and stained in its entirety (Starink et al. 1994b). Sediment was dispensed in $50 \mathrm{ml}$ centrifuge tubes (Nalgene) and stained with 5-([4,6-dichlorotriazin-2-yl]-amino)-fluorescein (DTAF) for $3 \mathrm{~h}$ in a water bath of $60^{\circ} \mathrm{C}$. DTAF was dissolved in a $0.05 \mathrm{M}$ $\mathrm{Na}_{2} \mathrm{HPO}_{4} / 2 \% \mathrm{NaCl}$ buffer of $\mathrm{pH} 9$, at a final concentration of $0.2 \mathrm{mg} \mathrm{ml}^{-1}$ (Sherr \& Sherr 1993b). Unbound dye was removed by repetitive (4 cycles) resuspension/centrifugation $(22000 \times g, 15 \mathrm{~min})$ in the phosphate buffer. After a last rinse with filtered-sterilized Schelde water, the sediment was frozen at $-28^{\circ} \mathrm{C}$. A few days later it was thawed for the grazing experiment.

Grazing experiments. In acid washed glass containers, freshly collected sediment was gently mixed with stained sediment so that $25 \%$ of the mixed sediment volume was stained sediment. It was placed in a water bath at the temperature of the Schelde water (Fig. 2B) and in the dark. Some filtered $(0.22 \mu \mathrm{m})$ water was added to facilitate the mixing. As both the stained and the fresh sediment were collected at the same place with only a few days in between, we assume that they have the same bacterial density, which means that $25 \%$ of the bacteria in the mixture was stained. Immediately after mixing, a subsample was taken in order to check this ratio. For each of the 2 sampling sites, 2 or 3 replicate containers were used.

In a preliminary experiment, the number of ingested FLB per flagellate was found to increase during the first 10 min of the incubation, but not thereafter. Therefore, after $10 \mathrm{~min}$ of incubation, a subsample was taken, with a small spoon, from each container. The subsamples were immediately fixed with an equal volume of ice-cold $4 \%$ glutaraldehyde. Flagellates were extracted, stained and collected on filters as described above. They were examined under epifluorescence illumination. UV-excitation was used to locate the flagellates and after switching to blue light excitation, the number of FLB inside the cells was counted. For each size class, 50 flagellates were examined. For flagellates larger than $20 \mu \mathrm{m}$, all flagellates on a filter were counted if the total number was $<50$. For each size class of flagellates, grazing rates were calculated from the total number of FLB ingested after 10 min incubation and the total number of flagellates examined, corrected for the percentage of stained bacteria and the incubation time.

Statistical analysis. For statistical analyses we used STATISTICA 5.1 for Windows (StatSoft, Inc., Tulsa, OK, USA). Bacterial density, bacterial production, flagellate density and chl a content were transformed by $\log (x)$, and the proportion of bacterial production consumed by flagellates was transformed by $\log (x+1)$ in order to obtain normal distribution of the data. Normality was tested using the Shapiro-Wilk's $W$-test. For Spearman rank and Pearson correlations and least squares regression analysis, data of the silty and the sandy site were pooled $(n=10)$.

\section{RESULTS}

Median grain size (mgs) of the sediment ranged from 177 to $214 \mu \mathrm{m}$ at the sandy site (Fig. 2A), which means that the sediment consists of fine sand all year around. At the silty site, the mgs was much lower (61 to $127 \mu \mathrm{m})$ and displayed larger seasonal fluctuations. In May and August mgs was lowest and the mud $(<63 \mu \mathrm{m})$ content was around $50 \%$ by volume at that time (not shown).

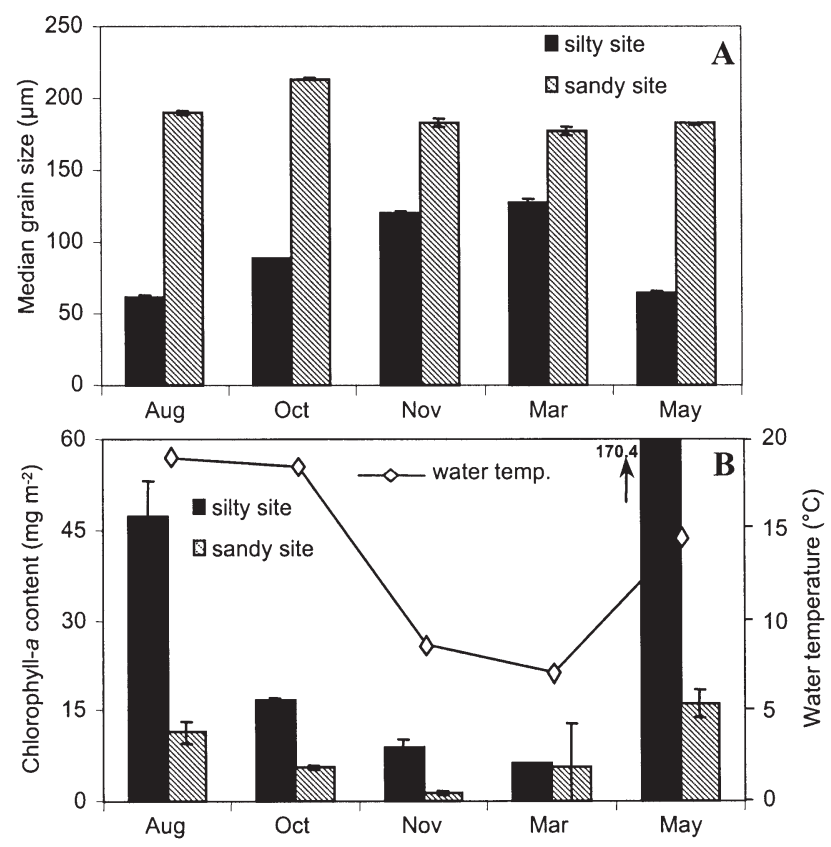

Fig. 2. (A) Mean median grain size $( \pm 1 \mathrm{SD}, \mathrm{n}=2)$ and (B) mean chl a content $( \pm 1 \mathrm{SD}, \mathrm{n}=2)$ at the silty site (black bars) and the sandy site (hatched bars) on the Molenplaat at the time of the experiments. In (B), temperature of the Schelde water near the sampling site at the time of the experiments is also shown 
The chl a content of the sediment ranged from 6.2 to $170.4 \mathrm{mg} \mathrm{m}^{-2}$ at the silty site and from 1.3 to $16.1 \mathrm{mg}$ $\mathrm{m}^{-2}$ at the sandy site (Fig. 2B). At both sites, maximal values were observed in May. There was a significant negative relation between chl a content and mgs (Table 1).

Bacterial density (Fig. 3A,B) decreased significantly with increasing mgs of the sediment (Table 1). At the silty site, bacterial density ranged between 1.5 and $5.8 \times 10^{9} \mathrm{cells} \mathrm{ml}^{-1}$, with highest numbers in late spring and summer (Fig. 3A). At the sandy site bacterial numbers were always lower, on average $5 \times 10^{8} \mathrm{cells} \mathrm{ml}^{-1}$ or ca $10 \%$ of values at the silty site, with only small seasonal fluctuations (Fig. 3B).

Densities of heterotrophic flagellates at the sandy site ranged from $0.6 \times 10^{5}$ cells ml ${ }^{-1}$ in November to $1.8 \times 10^{5}$ cells ml $^{-1}$ in May (Fig. 4A). At the silty site, flagellate numbers were much higher in May, when flagellate density was $5.2 \times 10^{5}$ cells $\mathrm{ml}^{-1}$, but were lower from October until March and were not different compared to the sandy site in August. The 2 sites differed strongly in the size distribution of the flagellates, with flagellates $<5 \mu \mathrm{m}$ dominating at the silty site $(63.6$ to $87.3 \%$ of total density), whereas at the sandy site,

Table 1. Spearman rank (with Water temp.) and Pearson (other variables) correlation coefficients. mgs: median grain size; mgr: mean grazing rate (see text); \% SS: proportion of standing stock grazed $\mathrm{d}^{-1}$; \% prod: proportion of daily bacterial production grazed $\mathrm{d}^{-1}$. Levels of significance are ${ }^{*} \mathrm{p}<0.05,{ }^{* *} \mathrm{p}<0.01,{ }^{* * *} \mathrm{p}<0.001$, ns: not significant

\begin{tabular}{|c|c|c|c|c|c|c|c|c|c|}
\hline Variable & Water temp. & mgs & Chl a & Bact dens. & Bact prod. & Flag dens. & Flag biom. & $\mathrm{mgr}$ & $\% \mathrm{SS}$ \\
\hline mgs & ns & & & & & & & & \\
\hline Chl a & ns & $-0.74^{*}$ & & & & & & & \\
\hline Bact dens. & ns & $-0.96^{* * *}$ & $0.77^{* *}$ & & & & & & \\
\hline Bact prod. & ns & $-0.72^{*}$ & $0.91^{* * *}$ & $0.81^{* *}$ & & & & & \\
\hline Flag dens. & $\mathrm{ns}$ & ns & $0.71^{*}$ & ns & ns & & & & \\
\hline Flag biom. & ns & ns & ns & ns & ns & $0.66^{*}$ & & & \\
\hline $\mathrm{mgr}$ & ns & $0.93^{* * *}$ & $-0.68^{*}$ & $-0.88^{* * *}$ & $-0.69^{*}$ & ns & ns & & \\
\hline$\% \mathrm{SS}$ & ns & $0.85^{* *}$ & ns & $-0.86^{* *}$ & ns & ns & $0.83^{* *}$ & $0.78^{* *}$ & \\
\hline \%prod. & ns & $0.82^{* *}$ & $-0.67^{*}$ & $-0.88^{* * *}$ & $-0.82^{* *}$ & ns & ns & $0.88^{* * *}$ & $0.79^{* *}$ \\
\hline
\end{tabular}
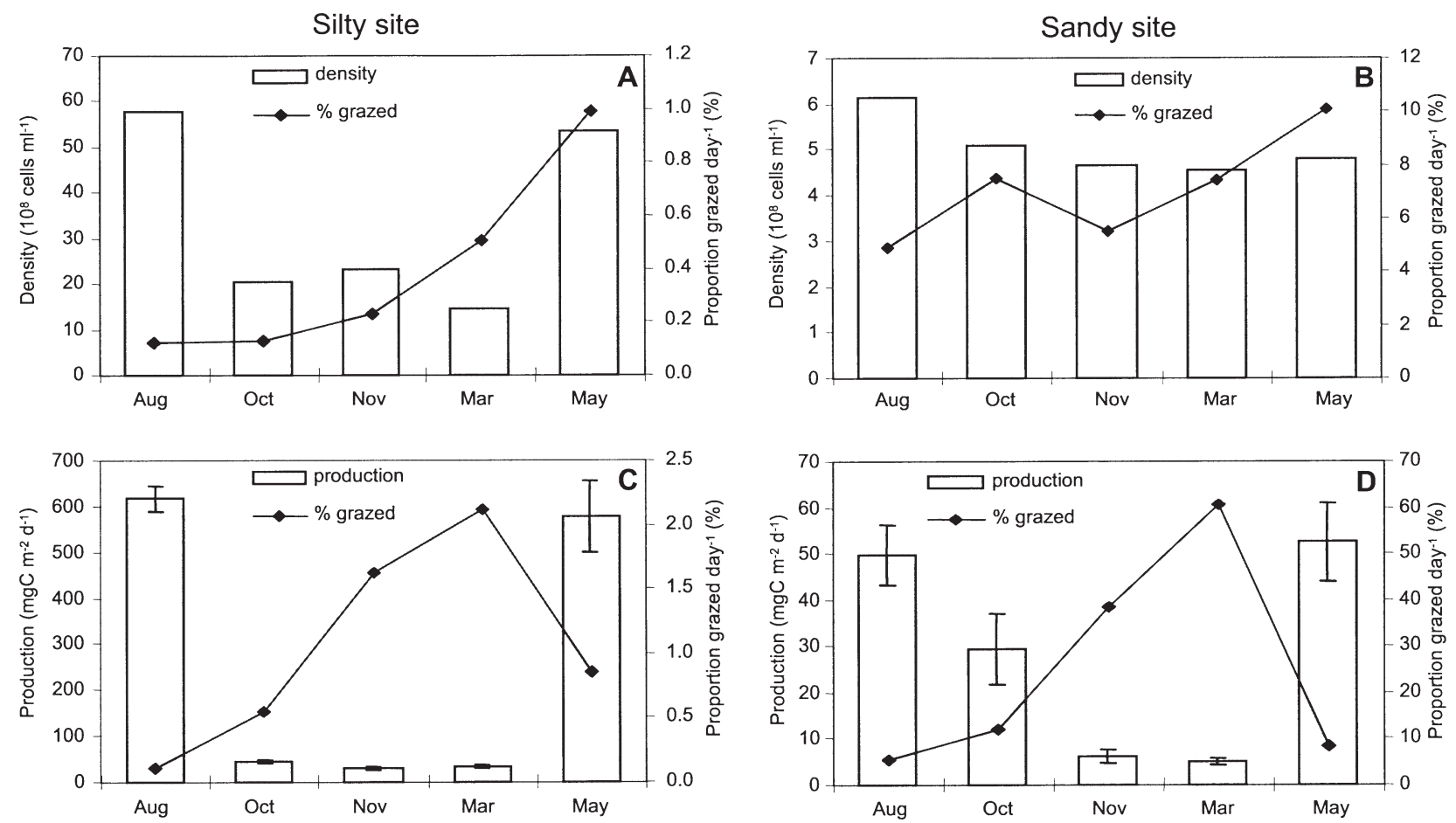

Fig. 3. Bacterial density $(A, B)$ and production (mean $\pm 1 S D, n=12)(C, D)$ at the silty site $(A, C)$ and the sandy site $(B, D)$ on the Molenplaat and grazing by flagellates $\left(\% \mathrm{~d}^{-1}\right)$ 

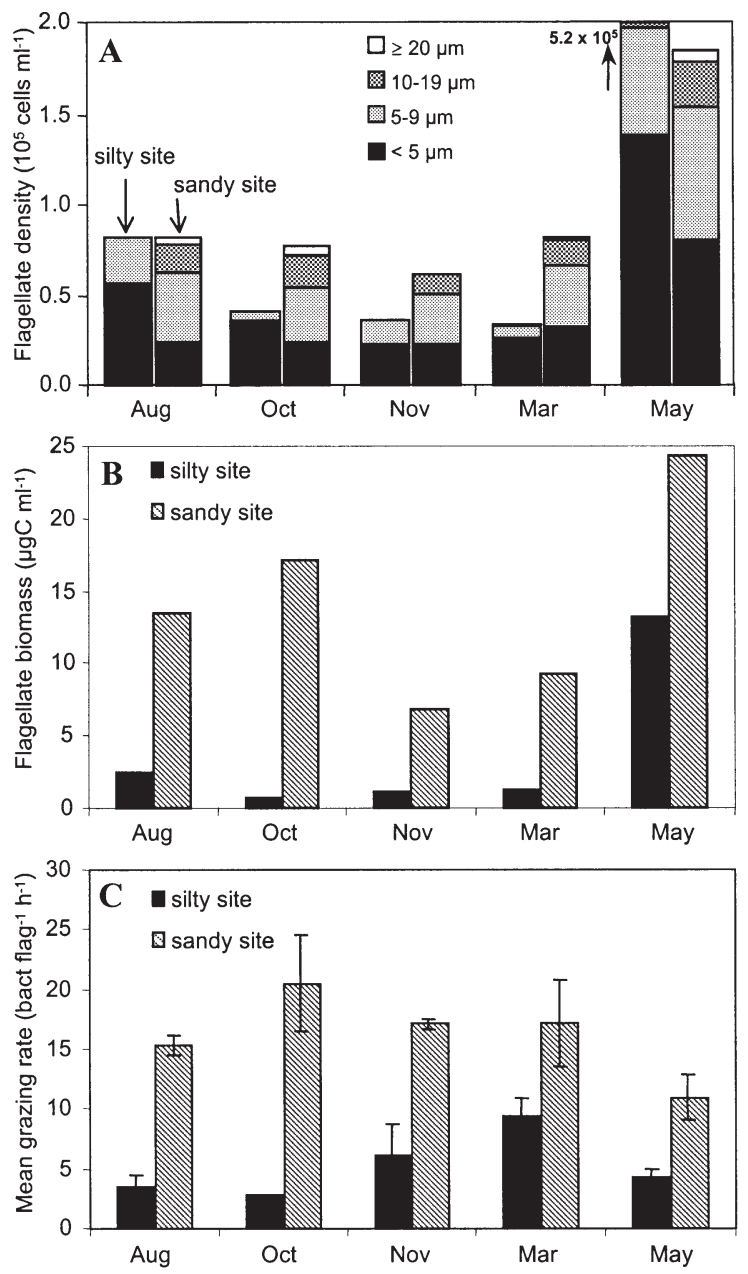

Fig. 4. (A) Flagellate density at the silty site (left bars) and the sandy site (right bars). Total density is subdivided proportional to the contribution of the different size classes. (B) Flagellate biomass and $(\mathrm{C})$ mean grazing rate $( \pm 1 \mathrm{SD}, \mathrm{n}=2$ or 3$)$ at the silty site (black bars) and the sandy site (hatched bars) on the Molenplaat

flagellates in the 5 to $9 \mu \mathrm{m}$ size class were on average more abundant (Fig. 4A). Flagellates $>20 \mu \mathrm{m}$ accounted for up to $6.7 \%$ of total flagellate density at the latter site, but were almost absent at the silty site. The observed differences in cell size are reflected in the flagellate biomass, which ranged from 0.7 to $13.2 \mu \mathrm{gC}$ $\mathrm{ml}^{-1}$ at the silty site and from 6.8 to $24.3 \mu \mathrm{gC} \mathrm{ml}^{-1}$ at the sandy site (Fig. 4B). Flagellate biomass was positively related to the mgs of the sediment, but the relation was not significant unless the exceptional value for the silty site in May was excluded (see Fig. 7B).

Bacterial production was always significantly higher at the silty site (30 to $618 \mathrm{mgC} \mathrm{m}^{-2} \mathrm{~d}^{-1}$, Fig. $3 \mathrm{C}$ ) when compared to the sandy site (5 to $52 \mathrm{mgC} \mathrm{m}^{-2} \mathrm{~d}^{-1}$, Fig. 3D) (Mann-Whitney $U$-tests, $\mathrm{p}<0.05$ ). At both sites, seasonal variation was highly significant
(Kruskal-Wallis, $\mathrm{p}<<0.01$ ), with highest values in May and August and low production in winter and early spring. There was no significant relationship between bacterial production and incubation temperature (Table 1). Bacterial production was significantly positively related to bacterial density and chl a content of the sediment, and significantly negatively related to the grain size of the sediment (Table 1). From bacterial densities and production, community growth rate was estimated. At both sites, community growth rate ranged from 0.1 to $1.2 \mathrm{~d}^{-1}$, with values above $1 \mathrm{~d}^{-1}$ limited to May and August and lowest values in winter and early spring (not shown).

Grazing rates were calculated for each flagellate size class separately. At the silty site, the near absence of flagellates $>20 \mu \mathrm{m}$ made it impossible to calculate grazing rates for this size class. Based on the relative proportion of the size classes in total flagellate density, the weighted mean of the grazing rates of the different size classes was calculated. For simplicity, the term 'mean grazing rate' will be used.

Grazing rates increased with the size of the flagellates at both sites (Fig. 5). Grazing rates ranged from $0.6-6.2$ bacteria flagellate ${ }^{-1} \mathrm{~h}^{-1}$ for flagellates $<5 \mu \mathrm{m}$ to 26.1-55.6 bacteria flagellate ${ }^{-1} \mathrm{~h}^{-1}$ for flagellates $>20 \mu \mathrm{m}$. Pairwise comparison of grazing rates between the silty and the sandy site (Fig. 5), for data from all experiments and for all size classes, showed that grazing rates were significantly higher at the sandy site (paired $t$-test, $\mathrm{p}<0.02$ ). The same holds for the mean grazing rates, which ranged from 2.7 to 9.1 bacteria flagellate ${ }^{-1} \mathrm{~h}^{-1}$ at the silty site and from 10.9 to 20.5 bacteria flagellate ${ }^{-1} \mathrm{~h}^{-1}$ at the sandy site (Fig. 4C).

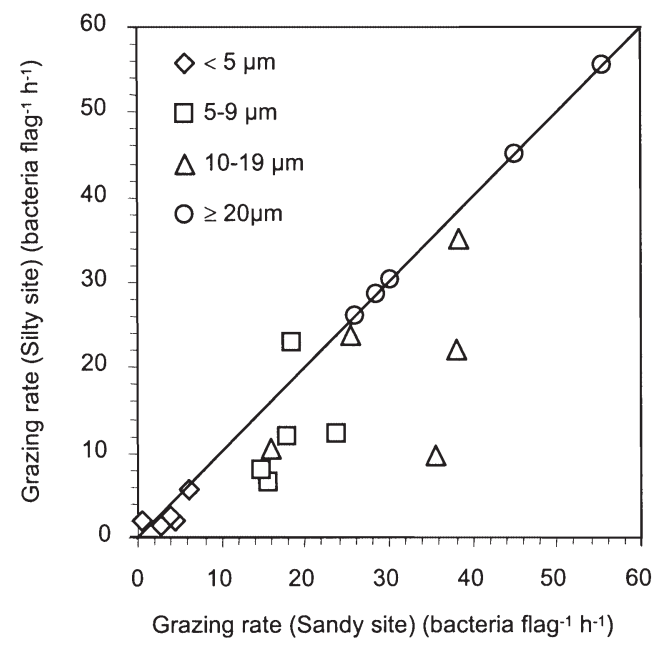

Fig. 5. Comparison of grazing rates at the silty and the sandy sites. Grazing rates for flagellates $\geq 20 \mu \mathrm{m}$ are for the sandy site, presented as if the same grazing rates were found for the silty site. Diagonal line represents the case in which the same grazing rate was found at both sites 
Mean grazing rate was significantly positively correlated with the mgs of the sediment and significantly negatively correlated with bacterial density and production (Table 1). The same correlations were found for the different size classes, although they were only significant for flagellates $>5 \mu \mathrm{m}$ (not shown). Grazing rates of the different size classes of flagellates, as well as mean grazing rates, did not vary significantly among dates (Kruskall-Wallis, $\mathrm{p}>0.05$ ). There was no significant relationship between temperature and mean grazing rate (Table 1) or grazing rates for the size classes 5 to 9 and 10 to $19 \mu \mathrm{m}$ (not shown). For flagellates $<5 \mu \mathrm{m}$, a significant negative relation of grazing rate with temperature was found (not shown).

The impact of flagellate grazing on the bacterial community is best expressed as the ratio of total consumption of bacteria by the flagellates over bacterial production. To enable comparison with some literature data, the portion of bacterial standing stock consumed per day by the flagellates was also estimated. Total prey consumption (product of grazing rates and flagellate densities) ranged from 2.6 to $4.8 \times 10^{7}$ bacteria $\mathrm{ml}^{-1}$ $\mathrm{d}^{-1}$ or from 2.4 to $4.5 \mathrm{mgC} \mathrm{m}^{-2} \mathrm{~d}^{-1}$ (not shown) at the sandy site. Between 74 and $92 \%$ of this consumption was accounted for by flagellates of 5 to $19 \mu \mathrm{m}$. At the silty site, total grazing was smaller between August and March. At that time, $<1 \times 10^{7}$ bacteria $\mathrm{ml}^{-1}$ or $1 \mathrm{mgC} \mathrm{m}^{-2}$ were grazed per day. In May, $5.3 \times 10^{7}$ bacteria $\mathrm{ml}^{-1} \mathrm{~d}^{-1}$, corresponding to $4.9 \mathrm{mgC} \mathrm{m}^{-2} \mathrm{~d}^{-1}$, were grazed by the flagellates. In each case, $>90 \%$ of the consumption at the silty site was accounted for by flagellates $<10 \mu \mathrm{m}$.

At the silty site, the total flagellate community consumed a maximum of $2.1 \%$ of bacterial production (Fig. 3C). This corresponds to a maximum of $1 \%$ of bacterial standing stock per day (Fig. 3a). At the sandy site respectively 4.9 to 10.1 and 5.6 to $60.4 \%$ of bacterial standing stock and production was grazed per day (Fig. 3B,D). The fraction of standing stock as well as the fraction of bacterial production grazed per day increased significantly with increasing grain size (Table 1). At both sites, the largest fraction of bacterial production was grazed in winter and early spring (maximum in March), and the smallest fraction in summer (minimum in August) (Fig. 3C,D).

\section{DISCUSSION}

Our bacterial abundance and production measurements are well within the range of values reported for other intertidal sediments (van Duyl \& Kop 1990, Cammen 1991, Epstein \& Shiaris 1992b, Hondeveld et al. 1992, Epstein 1997b, Kuwae \& Hosokawa 1999). Bacterial production and abundance were on average 7 times higher at the silty site than at the sandy site. At both sites, bacterial production peaked in May and August, but there was no significant relation with temperature. We found a significant negative relationship between bacterial production and median grain size as well as a positive relationship with the chl a content of the sediment. Multiple regression analysis, however, showed the chl a content to be the most important predictor of bacterial production (Fig. 6), accounting for $83 \%$ of the variance. The chl a content has been found to be highly correlated with the concentration of colloidal carbohydrates on the Molenplaat (C. H. Lucas pers. comm.) and in other intertidal sediments (e.g. Underwood et al. 1995, Underwood \& Smith 1998). These carbohydrates constitute a major part of the carbon fixed by microphytobenthos (Goto et al. 1999, Smith \& Underwood 2000) and may serve as an important substrate for bacteria (van Duyl et al. 1999, Goto et al. 2001). The strong relationship between bacterial production and the chl a content of the sediment therefore suggests that in our study bacterial production was mainly regulated by substrate supply. A close link between bacterial production and substrate supply has also been observed in other aquatic sediments (e.g. Cole et al. 1988, van Duyl \& Kop 1994, Bak et al. 1995) and for many pelagic systems (e.g. Cole et al. 1988, Sanders et al. 1992).

Although flagellate density was in May much higher at the silty site when compared to the sandy site, flagellate biomass was always higher at the sandy site, as larger forms dominated the community at that site. We found no significant relation between flagellate abundance or biomass and bacterial density, bacterial production or temperature. Flagellate biomass was found to be positively related to the median grain size of the sediment. Lower biomass of flagellates in silty com-

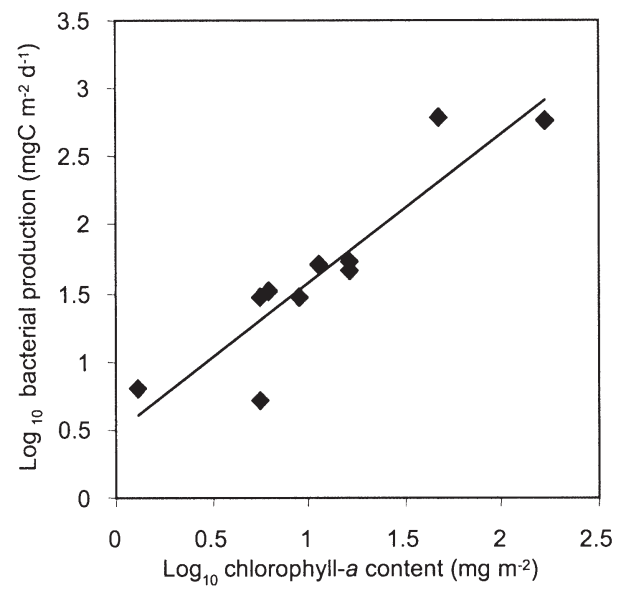

Fig. 6. Relation between bacterial production and chl a content. Regression: $y=0.49+1.09 x\left(R^{2}=0.83, p<0.0003\right)$ 
pared to sandy sediments was also found in other marine sediments (e.g. Bak et al. 1991, Bak \& Nieuwland 1993), although in these cases, the difference did not result from differences in the size distribution of the flagellates, but was entirely attributed to lower densities in silty sediments. Lower flagellate densities in silty sediments were ascribed to small interstitial spaces and adverse chemical conditions, like oxygen stress, prevailing in fine sediments. These circumstances may also explain why larger flagellates were mainly restricted to the sandy site in this study. Information on the effect of sediment characteristics on flagellate distribution is scarce however and very high densities were sometimes found in fine sediments (e.g. Tso \& Taghon 1997, this study at the silty site in May). Flagellates in silty sediments may possibly be concentrated temporarily in a small surface layer, rich in detritus or carbohydrates, comparable to microbial mats, which sometimes harbour high protozoan densities (Bernard \& Fenchel 1995). In experiments using artificial sediments, Young et al. (1994) found that the protozoan population decreased as particle size decreased. They suggest that decreasing the particle size reduced the feeding rate and so reduced the rate of population increase. A positive relation between feeding rate and particle size was observed in the present study and will be discussed below.

Our mean grazing rate estimates ( 2.7 to 20.5 bacteria flagellate $^{-1} \mathrm{~h}^{-1}$ ) are well within the range of values reported for other aquatic sediments (1 to 73 bacteria flagellate ${ }^{-1} \mathrm{~h}^{-1}$, in Bot \& Kaplan 1990, Novitsky 1990, Epstein \& Shiaris 1992b, Hondeveld et al. 1992, 1995, Starink et al. 1994b, 1996a). The highest values were reported by Starink (1994b, 1996a), who attributed this to the use of stained sediment instead of monodispersed FLB and a selection of flagellates for attached bacteria. Using the same method, our grazing rates are several times smaller than the values reported by Starink et al. (1996a) when comparing grazing rates for flagellates of approximately the same size. This suggests that factors other than method and cell size influence grazing rate estimates. In a multiple regression analysis, median grain size was found to be the most important predictor of flagellate mean grazing rate, accounting for $87 \%$ of the variance. No other factor added significantly to the regression. The strong correlation between sediment grain size and mean grazing rates (Fig. 7C) is related to flagellate size distributions as well as grazing rates of individual flagellate size classes. As has been observed in other studies (Hondeveld et al. 1992, Starink et al. 1996a, Epstein 1997a,b) grazing rates increased with the size of the flagellates, which tended to be higher at the sandy site. But our results also show that flagellates from sandy sediments consume significantly more bacteria compared to fla- gellates from the same size class in silty sediments. As far as we know, a similar observation has not been reported before for in situ experiments. Young et al. (1994, see above), suggest that a reduction in particle size reduces the amount of food available in each interstitial pore and would increase the time taken to explore the available pore volume, resulting in lower feeding rates in finer sediments. Furthermore, a modelling study of flagellate feeding currents has shown that surface and hydrodynamic forces have confounding effects on flagellate feeding (Monger \& Landry 1990). This effect is probably more important in finer sediments, where interstitial spaces are much smaller, and may result in lower feeding rates of flagellates. Finally, concentrations of unicellular algae, detrital particles and colloidal and dissolved organic matter are higher in silty sediments when compared to sandy sediments. These substances may serve as an alternative food source for flagellates (Sanders 1991). Flagellate species that depend primarily on osmotrophic nutrition or algivory will therefore most likely be found in silty sediments. But other species may also complete their bacterial diet with other food sources, thereby reducing mean bacterial uptake.

At the silty site, the flagellate community consumed only a minor part of bacterial standing stock $(1 \%)$ and daily production $(\leq 2.1 \%)$. At the sandy site, flagellates consumed 5 to $10 \%$ of bacterial standing stock and 6 to $60 \%$ of daily production. Pooled data from both sites show that the fraction of standing stock as well as the fraction of daily bacterial production grazed per day by flagellates, increased significantly with increasing median grain size. A low impact of flagellate grazing on bacterial populations of fine sediments was also found in other grazing studies: $0.2 \%$ of standing stock per day in a muddy tidal flat (Epstein \& Shiaris 1992b) and, despite high grazing rates, only 0.4 to $5.2 \%$ of daily bacterial production in fine freshwater lake sediments (Starink et al. 1996a). On the basis of grazing rates from Starink et al. (1994b), Dietrich \& Arndt (2000) estimated that only $3 \%$ of bacterial standing stock could be consumed by heterotrophic protozoa from marine muddy sands. In our study, a considerable impact on bacterial production (38 to $60 \%$ ) was only observed for the fine sandy sediments at the sandy site in winter and early spring, when bacterial production was lowest. In other studies, a considerable impact of flagellate grazing on bacterial production has only occasionally been reported and was, like in our study, always found to be restricted to fine sandy sediments (125 to $250 \mu \mathrm{m}$ median grain size) during a limited part of the year, when bacterial production was low (Hondeveld et al. 1995, Epstein 1997b). For an annual carbon budget, van Duyl et al. (1992), using a grazing rate of 50 bacteria flagellate ${ }^{-1} \mathrm{~h}^{-1}$, estimated that $1.4 \%$ of 
bacterial production could be consumed by flagellates from silty North Sea sediments while this amounted to $32 \%$ in sandy sites. In coarser sand, Hondeveld et al. (1995) and Epstein (1997a) did not observe a considerable impact of flagellates on bacterial production. Bott \& Kaplan (1990) estimated that 80 to $183 \%$ of the annual bacterial production in coarse streambed sediments was consumed by protozoa. Since they extrapolated grazing rates from laboratory experiments to field densities and production, these estimates should be treated with caution.

Our data together with literature data suggest that in most aquatic sediments, for a large part of the year, flagellate grazing has no considerable impact on bacterial community dynamics. By contrast, in pelagic communities grazing by heterotrophic flagellates is an important fate of bacterial production (Sherr \& Sherr 1994). In planktonic ecosystems both bacterial numbers and flagellate numbers increase with increasing productivity, in space as well as in time, thereby maintaining equilibrium between production of bacteria and flagellate grazing (Berninger et al. 1991, Sanders et al. 1992). In eutrophic waters, predation on flagellates can lead to a temporary uncoupling of bacterial production and flagellate grazing (Berninger et al. 1991, Gasol 1994). Our study suggests that in sediments, bacterial production increases with decreasing median grain size, resulting in high bacterial production in silty and muddy sediments (Fig. 7A). Flagellate biomass, on the other hand decreases with decreasing median grain of the sediment (Fig. 7B). Increases in bacterial productivity in space as well as over time are therefore usually not accompanied by an equivalent increase in flagellate grazing pressure. As a result, in fine sediments, bacterial production and grazing are strongly uncoupled. In comparison to silty sediments, bacterial production in sandier sediments is lower and flagellate biomass and grazing rates are higher, which results in flagellates having a stronger control over bacterial dynamics (Fig. 7C,D). A balance between bacterial production and grazing by flagellates is however rarely achieved and is probably restricted to periods when bacterial production is minimal. It seems unlikely that improved estimates of grazing rates for benthic flagellates will change these conclusions.

If flagellates are usually not the major consumers of bacteria in aquatic sediments, what then is the fate of

Fig. 7. Relationships between (A) bacterial production (B) flagellate biomass, (C) mean grazing rate, and (D) the proportion of bacterial production grazed per day by flagellates with the median grain size of the sediment. Regressions: (A) $y=2.9$ $0.0089 x\left(\mathrm{R}^{2}=0.52, \mathrm{p}<0.02\right)$; (B) $y=-9.64+0.1215 x\left(\mathrm{R}^{2}=0.57\right.$ without the silty site May, $\mathrm{p}<0.02)$; (C) $y=-4.74+0.11 x\left(\mathrm{R}^{2}=\right.$ $0.87, \mathrm{p}<0.00008) ;(\mathrm{D}) \mathrm{y}=-0.46+0.0088 \mathrm{x}\left(\mathrm{R}^{2}=0.67, \mathrm{p}<0.004\right)$

benthic bacterial production? Apart from flagellates, benthic ciliates (Kemp 1988), naked amoebae (Butler \& Rogerson 1997), meio- (Epstein 1997b) and macrofauna (Kemp 1987) may consume bacteria. Even bacterial predators of bacteria have been found in estuarine sediments (Rice et al. 1998). Ciliates typically have a maximum occurrence in fine sands (Fenchel 1969), which is in accordance with high densities at the sandy site on the Molenplaat (Hamels et al. 1998). From estimates of bacterivorous ciliate numbers (I. Hamels unpubl. data) and assuming a mean grazing rate of 260 bacteria cell ${ }^{-1} \mathrm{~h}^{-1}$ (Kemp 1988), ciliates could consume $\sim 2$ to $7 \%$ of bacterial production at the sandy site. At the silty site, the estimated impact of ciliate grazing on bacterial production is very low $(<<1 \%)$. These estimates are comparable with measurements by Kemp (1988) and Epstein (1997a) for muddy and sandy intertidal sediments. Nematodes are the dominant meiofauna in intertidal sediments of the Schelde estuary (81 to $98 \%$, Soetaert et al. 1994), densities generally being higher in siltier sediments. At the sandy site on the Molenplaat, the nematode community of the upper $2 \mathrm{~cm}$ of the sediment is dominated by a predatory species which does not graze bacteria (Moens et al. 1999). Bacterivorous nematodes are more abundant at the silty site (M. Steyaert pers. comm.); however, the ratio of bacterial to nematode density exceeds $10^{7}$, making control of bacteria by nematodes unlikely (Kemp 1990). Deposit feeding macrofauna are slightly more abundant at the silty site (P. M. J. Herman pers. comm.). While bacteria may constitute a significant carbon and especially nitrogen source for depositfeeding macrobenthos (Lopez \& Levinton 1987), there is little evidence to suggest that macrobenthos is capable of reducing or controlling bacterial abundance (Kemp 1990). In conclusion it seems that in silty sediments, like our silty site, with high bacterial production probably resulting from high substrate supply, most of this production remains unaffected by grazers. In some sandy sediments, like our sandy site, grazing may be a more important fate of bacterial production.

Apart from being grazed, bacterial production may be lost by the lytic action of viruses. Estimates of the impact of viral lysis on bacterial dynamics in aquatic sediments are still lacking. It is likely, however, that viral infections will spread more easily and consequently more strongly affect bacterial dynamics where bacterial density is higher. Furthermore, the majority of sediment bacteria is associated with particles and bacteria are often found in sheltered areas, such as fissures in sand grains and within detritus particles (Weisse \& Rheinheimer 1978). Given the higher internal surface and the higher amount of detritus particles in silty sediments, it is likely that a considerable portion of the bacteria in those sediments is not available for grazers, except those that engulf the sediment as a whole. A substantial part of bacterial production in silty sediments may thus become buried and/or suffer viral lysis.

Acknowledgements. This research was performed within the framework of the EU Environment \& Climate programme ECOFLAT (ENV4-CT96-0216), which is part of the ELOISE programme (publication no. 224). I.H. acknowledges a grant from the Fund for Scientific Research, Flanders (FWO G.0104.99), K.M. is a postdoctoral fellow of the same Fund, and funding also came from GOA (12-05398). We thank the Netherlands Institute of Ecology-Centre for Estuarine and Coastal Ecology (NIOO-CEMO) for the use of the RV 'Luctor', and also the crew and Jan Peene for assistance. Dr S. Epstein, Dr F. van Duyl and Dr M. Starink are thanked for stimulating discussions about the methodology. Thanks to Prof. V. N. de Jonge for valuable comments and to Dirk van Gansbeke for the chlorophyll analyses.

\section{LITERATURE CITED}

Bak RPM, Nieuwland G (1993) Patterns in pelagic and benthic nanoflagellate densities in the coastal upwelling system along the Banc d'Arguin, Mauritania. Hydrobiol 258: 119-131

Bak RPM, van Duyl FC, Nieuwland G, Kop AJ (1991) Benthic heterotrophic nanoflagellates in North Sea field mesocosm bottoms and their response to algal sedimentation. Ophelia 33:187-196

Bak RPM, van Duyl FC, Nieuwland G (1995) Organic sedimentation and macrofauna as forcing factors in marine benthic nanoflagellate communities. Microb Ecol 29:173-182

Bernard C, Fenchel T (1995) Mats of colourless sulphur bacteria. II. Structure, composition of biota and successional patterns. Mar Ecol Prog Ser 128:171-179

Berninger UG, Finlay BJ, Kuuppo-Leinikki P (1991) Protozoan control of bacterial abundances in freshwater. Limnol Oceanogr 36:139-147

Borchardt MA, Bott TL (1995) Meiofaunal grazing of bacteria and algae in a Piedmont stream. J N Am Benthol Soc 14: $278-298$

Børsheim KY, Bratbak G (1987) Cell volume to cell carbon conversion factors for a bacterivorous Monas sp. enriched from seawater. Mar Ecol Prog Ser 36:171-175

Bott TL, Kaplan LA (1990) Potential for protozoan grazing of bacteria in streambed sediments. J N Am Benthol Soc 9: 336-345

Bratbak G, Dundas I (1984) Bacterial dry matter content and biomass estimations. Appl Environ Microbiol 48:755-757

Butler H, Rogerson A (1997) Consumption rates of six species of marine benthic naked amoebae (Gymnamoebia) from sediments in the Clyde Sea area. J Mar Biol Assoc UK 77 : 989-997

Cammen LM (1991) Annual bacterial production in relation to benthic microalgal production and sediment oxygen uptake in an intertidal sandflat and an intertidal mudflat. Mar Ecol Prog Ser 71:13-25

Cammen LM, Walker JA (1986) The relationship between bacteria and microalgae in the sediment of a Bay of Fundy mudflat. Estuar Coast Shelf Sci 22:91-99

Caron DA (1987) Grazing of attached bacteria by heterotrophic microflagellates. Microb Ecol 13:203-218

Cole JJ, Findlay S, Pace ML (1988) Bacterial production in 
fresh and saltwater ecosystems: a cross-system overview. Mar Ecol Prog Ser 43:1-10

Dietrich D, Arndt H (2000) Biomass partitioning of benthic microbes in a Baltic inlet: relationships between bacteria, algae, heterotrophic flagellates and ciliates. Mar Biol 136: 309-322

Epstein SS (1997a) Microbial food webs in marine sediments. I. Trophic interactions and grazing rates in two tidal flat communities. Microb Ecol 34:188-198

Epstein SS (1997b) Microbial food webs in marine sediments. II. Seasonal changes in trophic interactions in a sandy tidal flat community. Microb Ecol 34:199-209

Epstein SS, Shiaris MP (1992a) Size-selective grazing of coastal bacterioplankton by natural assemblages of pigmented flagellates, colorless flagellates, and ciliates. Microb Ecol 23:211-225

Epstein SS, Shiaris MP (1992b) Rates of microbenthic and meiobenthic bacterivory in a temperate muddy tidal flat community. Appl Environ Microbiol 58:2426-2431

Fenchel T (1969) The ecology of marine microbenthos. IV. Structure and function of the benthic ecosystem, its chemical and physical factors and the microfauna communities with special reference to the ciliated protozoa. Ophelia 5: $1-182$

Gasol JM (1994) A framework for the assessment of top-down vs bottom-up control of heterotrophic nanoflagellate abundance. Mar Ecol Prog Ser 113:291-300

Goto N, Kawamura T, Mitamura O, Terai H (1999) Importance of extracellular organic carbon production in the total primary production by tidal flat diatoms in comparison to phytoplankton. Mar Ecol Prog Ser 190:289-295

Goto N, Mitamura O, Terai H (2001) Biodegradation of photosynthetically produced extracellular organic carbon from intertidal benthic algae. J Exp Mar Biol Ecol 257:73-86

Hahn MW, Höfle MG (1999) Flagellate predation on a bacterial model community: interplay of size-selective grazing, specific bacterial cell size, and bacterial community composition. Appl Environ Microbiol 65:4863-4872

Hamels I, Sabbe K, Muylaert K, Barranguet C, Lucas C, Herman P, Vyverman W (1998) Organisation of microbenthic communities in intertidal estuarine flats, a case study from the Molenplaat (Westerschelde Estuary, the Netherlands). Eur J Protistol 34:308-320

Hansen JA, Alongi DM (1991) Bacterial productivity and benthic standing stocks in a tropical coastal embayment. Mar Ecol Prog Ser 68:301-310

Herman PMJ, Middelburg JJ, Widdows J, Lucas CH, Heip CHR (2000) Stable isotopes as trophic tracers: combining field sampling and manipulative labelling of food resources for macrobenthos. Mar Ecol Prog Ser 204:79-92

Hondeveld BJM, Bak RPM, van Duyl FC (1992) Bacterivory by heterotrophic nanoflagellates in marine sediments measured by uptake of fluorescently labeled bacteria. Mar Ecol Prog Ser 89:63-71

Hondeveld BJM, Nieuwland G, van Duyl FC, Bak RPM (1994) Temporal and spatial variations in heterotrophic nanoflagellate abundance in North Sea sediments. Mar Ecol Prog Ser 109:235-243

Hondeveld BJM, Nieuwland G, van Duyl FC, Bak RPM (1995) Impact of nanoflagellate bacterivory on benthic bacterial production in the North Sea. Neth J Sea Res 34:275-287

Kemp PF (1987) Potential impact on bacteria of grazing by a macrofaunal deposit-feeder, and the fate of bacterial production. Mar Ecol Prog Ser 36:151-161

Kemp PF (1988) Bacterivory by benthic ciliates: significance as a carbon source and impact on sediment bacteria. Mar Ecol Prog Ser 49:163-169
Kemp PF (1990) The fate of benthic bacterial production. Rev Aquat Sci 2:109-124

Kuwae T, Hosokawa Y (1999) Determination of abundance and biovolume of bacteria in sediments by dual staining with $4^{\prime}, 6$-diamidino-2-phenylindole and acridine orange: relationship to dispersion treatment and sediment characteristics. Appl Environ Microbiol 65:3407-3412

Lopez GR, Levinton JS (1987) Ecology of deposit-feeding animals in marine sediments. Q Rev Biol 62:235-260

Mantoura RFC, Llewellyn CA (1983) The rapid determination of algal chlorophyll and carotenoid pigments and their breakdown products in natural waters by reverse-phase high-performance liquid chromatography. Anal Chim Acta 151:297-314

Middelburg JJ, Barranguet C, Boschker HTS, Herman PMJ, Moens T, Heip CHR (2000) The fate of intertidal microphytobenthos carbon: an in situ ${ }^{13} \mathrm{C}$ labeling study. Limnol Oceanogr 45:1224-1234

Moens T, Verbeeck L, Vincx M (1999) Feeding biology of a predatory and a facultatively predatory nematode (Enoploides longispiculosus and Adoncholaimus fuscus). Mar Biol 134:585-593

Monger BC, Landry MR (1990) Direct-interception feeding by marine zooflagellates: the importance of surface and hydrodynamic forces. Mar Ecol Prog Ser 65:123-140

Montagna PA (1984) In situ measurement of meiobenthic grazing rates on sediment bacteria and edaphic diatoms. Mar Ecol Prog Ser 18:119-130

Montagna PA (1995) Rates of metazoan meiofaunal microbivory: a review. Vie Milieu 45(1):1-9

Novitsky JA (1990) Protozoa abundance, growth, and bacterivory in the water column, on sedimenting particles, and in the sediment of Halifax Harbor. Can J Microbiol 36: $859-863$

Pérez-Uz B (1996) Bacterial preferences and growth kinetic variation in Uronema Marinum and Uronema Nigricans (Ciliophora: Scuticociliatida). Microb Ecol 31:189-198

Rice TD, Williams HN, Turng BF (1998) Susceptibility of bacteria in estuarine environments to autochthonous Bdellovibrios. Microb Ecol 35:256-264

Sanders RW (1991) Trophic strategies among heterotrophic flagellates. In: Patterson DJ, Larsen J (eds) The biology of free-living heterotrophic flagellates. The Systematics Association, Special Volume No. 45, Claredon Press, Oxford, p 21-38

Sanders RW, Caron DA, Berninger UG (1992) Relationships between bacteria and heterotrophic nanoplankton in marine and fresh waters: an inter-ecosystem comparison. Mar Ecol Prog Ser 86:1-14

Sherr EB, Sherr BF (1993a) Preservation and storage of samples for enumeration of heterotrophic protists. In: Kemp PF, Sherr BF, Sherr EB, Cole JJ (eds) Handbook of methods in aquatic microbial ecology. Lewis Publishers, Boca Raton, p 207-212

Sherr EB, Sherr BF (1993b) Protistan grazing rates via uptake of fluorescently labeled prey. In: Kemp PF, Sherr BF, Sherr EB, Cole JJ (eds) Handbook of methods in aquatic microbial ecology. Lewis Publishers, Boca Raton, p 695-701

Sherr EB, Sherr BF (1994) Bacterivory and herbivory: key roles of phagotrophic protists in pelagic food webs. Microb Ecol 28:223-235

Sibbald MJ, Albright LJ (1988) Aggregated and free bacteria as food sources for heterotrophic microflagellates. Appl Environ Microbiol 54:613-616

Simon M, Azam F (1989) Protein content and protein synthesis rates of planktonic marine bacteria. Mar Ecol Prog Ser 51:201-213 
Smith DJ, Underwood GJC (2000) The production of extracellular carbohydrates by estuarine benthic diatoms: the effects of growth phase and light and dark treatment. J Phycol 36:321-333

Soetaert K, Vincx M, Wittoeck J, Tulkens M, Vangansbeke D (1994) Spatial patterns of Westerschelde meiobenthos. Estuar Coast Shelf Sci 39:367-388

Starink M, Bär-Gilissen MJ, Bak RPM, Cappenberg TE (1994a) Quantitative centrifugation to extract benthic protozoa from freshwater sediments. Appl Environ Microbiol 60:167-173

Starink M, Krylova IN, Bär-Gilissen MJ, Bak RPM, Cappenberg TE (1994b) Rates of benthic protozoan grazing on free and attached sediment bacteria measured with fluorescently stained sediment. Appl Environ Microbiol 60: 2259-2264

Starink M, Bär-Gilissen MJ, Bak RPM, Cappenberg TE (1996a) Bacterivory by heterotrophic nanoflagellates and bacterial production in sediments of a freshwater littoral system. Limnol Oceanogr 41:62-69

Starink M, Bär-Gilissen MJ, Bak RPM, Cappenberg TE (1996b) Seasonal and spatial variations in heterotrophic nanoflagellate and bacteria abundances in sediments of a freshwater littoral zone. Limnol Oceanogr 41:234-242

Sundbäck K, Nilsson P, Nilsson C, Jönsson, B (1996) Balance between autotrophic and heterotrophic components and processes in microbenthic communities of sandy sediments: a field study. Estuar Coast Shelf Sci 43:689-706

Tso SF, Taghon GL (1997) Enumeration of protozoa and bacteria in muddy sediment. Microb Ecol 33:144-148

Underwood GJC, Smith DJ (1998) Predicting epipelic diatom

Editorial responsibility: John Dolan,

Villefranche-sur-Mer, France exopolymer concentrations in intertidal sediments from sediment chlorophyll a. Microb Ecol 35:116-125

Underwood GJC, Paterson DM, Parkes RJ (1995) The Measurement of microbial carbohydrate exopolymers from intertidal sediments. Limnol Oceanogr 40:1243-1253

van Duyl FC, Kop AJ (1990) Seasonal patterns of bacterial production and biomass in intertidal sediments of the western Dutch Wadden Sea. Mar Ecol Prog Ser 59: 249-261

van Duyl FC, Kop AJ (1994) Bacterial production in North Sea sediments: clues to seasonal and spatial variations. Mar Biol 120:323-337

van Duyl FC, Bak RPM, Kop AJ, Nieuwland G, Berghuis EM, Kok A (1992) Mesocosm experiments: mimicking seasonal developments of microbial variables in North Sea sediments. Hydrobiol 235:267-281

van Duyl FC, De Winder B, Kop AJ, Wollenzien U (1999) Tidal coupling between carbohydrate concentrations and bacterial activities in diatom-inhabited intertidal mudflats. Mar Ecol Prog Ser 191:19-32

Velji MI, Albright LJ (1993) Improved sample preparation for enumeration of aggregated aquatic substrate bacteria. In: Kemp PF, Sherr BF, Sherr EB, Cole JJ (eds) Handbook of methods in aquatic microbial ecology. Lewis Publishers, Boca Raton, p 139-142

Weisse T, Rheinheimer G (1978) Scanning electron microscopy and epifluorescence investigations of bacterial colonization of marine sand sediments. Microb Ecol 4:175-188

Young IM, Roberts A, Griffiths BS, Caul S (1994) Growth of a ciliate protozoan in model ballotini systems of different particle sizes. Soil Biol Biochem 26:1173-1178

Submitted: February 5, 2001; Accepted: April 17, 2001

Proofs received from author(s): August 2, 2001 